\title{
PEMANFAATAN POJOK LAKTASI DI PUSKESMAS I CILONGOK KABUPATEN BANYUMAS
}

\author{
Khusnul Khotimah ${ }^{1}$, Ova Emilia², Mohammad Hakimi ${ }^{3}$
}

\begin{abstract}
Background: Based on Indonesian Demographic and Health Survey in 2007 that exclusive breastfeeding prevalence is 38\%, decrease 5 from 39,5\% in 2002-2003. Child under 6 months who gets milk increase from 16,7\% to 27,9\% in 2007. American Academy of Pediatrics recommends that baby must get exclusive breastfeeding for 6 month until 2 years old. Banyumas district has a program to increase exclusive breastfeeding by head of district decree no 52 (2012). One of the material is about provision and standardization of room, right of breastfeeding worker in office and public facility.

Objective: To determine factors affected the utilization of lactation room in Puskesmas I Cilongok.

Methods: This study was an observational study with a cross sectional design and qualitative study located in Puskesmas I Cilongok. Sampling used sampling convenience involved 41 women during the period of study. Independent variables were attitude of breastfeeding mother about lactation room and behavior of breastfeeding mother. Dependent variable was utilization of lactation room. Data analysis consisted of univariate analysis, bivariate analysis using chi-square test and multivariate analysis using logistic regression test and also qualitative analysis.

Results and Discussion: Attitude of breastfeeding mother about lactation room was not related to utilization of lactation room ( $p=0,247, \mathrm{RP} 1,58 ; 95 \% \mathrm{Cl} 0,70-3,55)$. The in depth interview also revealed that these mothers has not get socialization from health worker. The good behavior of breastfeeding mother related to utilization $(p=0,028$, RP 2,35;95\% Cl 1,05-5,23). This was also confirmed by the interview. Utilization of lactation room was only for breastfeeding, and not used to pump and save breastmilk. People respond that lactation room is not necessary, and without policy on lactation room, they still can breastfeed any where.

Conclusion:Good attitude of breastfeeding mother about lactation room do not affect utilization of lactation room and good behavior breastfeeding mother can affect the utilization of lactation room in Puskesmas I Cilongok.
\end{abstract}

Keyword: attitude, breastfeeding mother, behavior of breastfeeding mother and utilization lactation room

\begin{abstract}
ABSTRAK
Latar Belakang: Berdasarkan data Survey Demografi dan Kesehatan Indonesia (SDKI) tahun 2007 tercatat bahwa cakupan ASI eksklusif sebesar 38\% menurun dari 39,5\%di tahun 2002-2003, sementara jumlah bayi dibawah 6 bulan yang diberi susu formula meningkat dari $16,7 \%$ menjadi $27,9 \%$ ditahun 2007. American Academy of Pediatrics ${ }^{1}$ merekomendasikan bahwa durasi minimal ASI eksklusif menjadi 6 bulan tetapi optimal harus terus selama minimal 2 tahun. Kabupaten Banyumas sedang memiliki program guna meningkatkan cakupan ASI eksklusif yang dituangkan lewat peraturan Bupati Banyumas nomor 52 tahun 2012. Salah satu materi tersebut berisi tentang anjuran pengadaan pojok laktasi beserta standarisasinya, hak ibu bekerja yang menyusui di kantor pemerintahan dan sarana pra sarana umum.

Tujuan: Untuk mengetahui faktor-faktor yang mempengaruhi pemanfaatan pojok laktasi di Puskesmas I Cilongok. Metode: Penelitian ini menggunakan jenis observasional dengan desain cross sectional dan kualitatif. Tempat penelitian Puskesmas I Cilongok. Sampel penelitian ibu bekerja menyusui dan pengunjung puskesmas memiliki bayi umur 0 bulan sampai dengan 2 tahun berada di Puskesmas I Cilongok. Pengambilan sampel menggunakan
\end{abstract}

Magister Kesehatan Ibu dan Anak KR, Pasca Sarjana, FK UGM

2,3 Bagian Ilmu Kebidanan dan Penyakit Kandungan, FK UGM, Yogyakarta 
sampling convinience diperoleh 41 orang selama penelitian dilakukan. Variabel independen adalah sikap ibu menyusui terhadap pojok laktasi, perilaku ibu menyusui. Variabel dependen ialah pemanfaatan pojok laktasi. Analisa data meliputi analisis univariabel, bivariabel dengan menggunakan chi square sedangkan multivariabel menggunakan uji regresi logistik serta analisis kualitatif.

Hasil dan Pembahasan: Sikap ibu menyusui terhadap ketersediaan pojok laktasi tidak mempengaruhi pemanfaatan pojok laktasi dilihat dari nilai $p=0,247$ ( $R P 1,58 ; 95 \% \mathrm{Cl} 0,70-3,55)$, hasil ini didukung hasil wawancara bahwa sikap baik tetapi tidak memanfaatkan pojok laktasi dengan alasan sosialisasi yang kurang dari petugas kesehatan. Perilaku ibu menyusui yang baik berhubungan dengan pemanfaatan pojok laktasi dilihat dari nilai $p=0,028$, RP2,35 (95\% Cl 1,05-5,23). Hasil wawancara ibu yang berperilaku tidak baik cenderung tidak memanfaatkan pojok laktasi. Pemanfaatan pojok laktasi hanya untuk menyusui saja, tidak digunakan untuk memeras dan penyimpanan ASI. Rendahnya pemanfaatan pojok laktasi dikarenakan faktor kebutuhan. Masyarakat desa tidak menganggap bahwa pojok laktasi merupakan kebutuhan, karena tanpa adanya kebijakan pengadaan pojok laktasi mereka dapat menyusui dimanapun.

Kesimpulan: Sikap ibu menyusui terhadap ketersediaan pojok laktasi yang baik tidak mempengaruhi pemanfaatan pojok laktasi dan perilaku ibu menyusui yang baik dapat mempengaruhi pemanfaatan pojok laktasi di Puskesmas I Cilongok Kabupaten Banyumas.

Kata kunci: sikap ibu, perilaku ibu, pemanfaatan pojok laktasi

\section{PENDAHULUAN}

Berdasarkan data Survei Demografi dan Kesehatan Indonesia (SDKI) tahun 2007 tercatat bahwa cakupan ASI eksklusif sebesar $38 \%$ menurun dari 39,5\% di tahun 2002-2203, sementara jumlah bayi dibawah 6 bulan yang diberi susu formula meningkat dari $16,7 \%$ menjadi $27,9 \%$ ditahun $2007 .{ }^{2}$ Hal ini disebabkan antara lain masih adanya stigma dan stereotipe bahwa menyusui merupakan urusan perempuan/ibu saja yang selama ini masih melekat dengan erat di sebagian besar masyarakat Indonesia. Pandangan ini sangat bias gender, pada hakikatnya memang perempuan yang memiliki kodrat untuk menyusui, namun laki-laki sangat berperan penting dalam dukungan bagi ibu untuk terus menyusui sehingga tercapai keberhasilan menyusui eksklusif hingga usia 6 bulan dan dilanjutkan dengan ASI dan makanan pendamping ASI hingga anak berusia dua tahun.

Cakupan ASI eksklusif di Jawa Tengah cukup rendah dan menurun dalam dua tahun terakhir, rendahnya pengetahuan ibu tentang ASI eksklusif menjadi pemicu masalah para konselor ASI di Kabupaten Banyumas. Cakupan ASI eksklusif di 43 persen masih jauh dari target nasional yang mencapai 80 persen, tercatat pada tahun 2012. Cakupan ASI eksklusif Kabupaten Banyumas masih jauh dari target. ${ }^{3}$

Kabupaten Banyumas sedang memiliki program guna meningkatkan cakupan ASI eksklusif yang dituangkan lewat Peraturan Bupati Banyumas nomor 52 tahun 2012 tentang peningkatan pemberian ASI di Kabupaten Banyumas. Program tersebut sedang digalakkan dengan mensosialisasikan kepada pengelola-pengelola fasilitas umum di Purwokerto, seperti stasiun kereta api, kepala rumah sakit, perkantoran, kantor bank, pusat perbelanjaan, dll. Salah satu bentuk materi sosialisasi tersebut berisi tentang anjuran pengadaan pojok laktasi beserta standarisasinya, hak ibu bekerja yang menyusui di kantor pemerintahan, fasilitas dan sarana umum juga. ${ }^{4}$ Pojok ASI berdasarkan PP nomor 33 tahun 2013 termasuk dalam pelayanan kesehatan yang harus disediakan di fasilitas kesehatan.

Menurut Anderson" dalam teori "A Behaviour Models of Families Use of Health services", ada tiga faktor yang mempengaruhi pemanfaatan pelayanan kesehatan, yaitu komponen predisposing, komponen enabling, komponen need. Hal ini diperkuat dengan pendapat lain dalam teori Health Belief Model bahwa perilaku dipengaruhi kepercayaan, persepsi, variabel sosial, demografi, pengetahuan, kebudayaan, 
ancaman, manfaat dan terdapatnya faktor pencetus isyarat untuk bertindak. selain itu adalah faktor necessary dan bukan sufficient terjadinya perubahan perilaku ${ }^{6}$. Tujuan penelitian ini adalah untuk mengetahui faktor-faktor yang mempengaruhi Pemanfaatan Pojok Laktasi di Puskesmas I Cilongok.

\section{METODE}

Jenis penelitian yang akan digunakan adalah observasional dengan pendekatan cross sectionaldan penelitian kualitatif.Penelitian kuantitatif yang digunakan adalah penelitian dengan pendekatan cross sectional.

Penelitian cross sectional adalah penelitian yang seluruh variabel diamati dan diukur pada waktu penelitian yang sedang berlangsung. Sedangkan penelitian kualitatif adalah suatu jenis penelitian yang temuan-temuannya tidak diperoleh melalui prosedur statistik atau bentuk hitungan lainnya tapi mencari jawaban atas pertanyaan mengapa, dan bagaimana suatu keputusan diambil oleh subyek, bukan sekedar apa, dimana dan bilamana. Penelitian kualitatif lebih mengutamakan jumlah subyek yang sedikit namun terfokus daripada sekedar jumlah subyek yang banyak ${ }^{7}$.

Tempat penelitian dilaksanakan di Puskesmas I Cilongok. Waktu Penelitian dilaksanakan pada Bulan September-Oktober 2013. Populasi penelitian ini merupakan semua ibu bekerja yang menyusui dan pengunjung Puskesmas I Cilongok yang memiliki bayi umur 0 bulan sampai 2 tahun yang berada di Puskesmas I Cilongok Kabupaten Banyumas. Sampel penelitian adalah pegawai puskesmas yang menyusui dan pengunjung Puskesmas I Cilongok yang memiliki bayi umur 0 bulan sampai dengan 2 tahun yang berada di Puskesmas I Cilongok Kabupaten Banyumas. Sampel yang digunakan menggunakan sampling convenience dan diperoleh 41 orang responden.

Analisis data dilakukan secara deskriptif yaitu data yang telah terkumpul akan diolah secara manual, kemudian selanjutnya akan diolah menggunakan software program STATA versi 9.0 Universitas Gadjah Mada, analisis yang digunakan adalah chisquare. Dengan Ratio Prevalence (RP) diambil dari eksponen beta dengan confidence interval (Cl) 95\%. Jenis penelitian kualitatif digunakan untuk mendukung hasil penelitian kuantitatif.

\section{HASIL DAN PEMBAHASAN}

\section{Karakteristik Responden}

Ibu menyusui yang menjadi responden memiliki karakteristik yang dapat dilihat pada tabel 1 sebagai berikut.

Tabel 1. Karakteristik responden

\begin{tabular}{lcc}
\hline \multicolumn{1}{c}{ Karakteristik responden } & $\mathbf{n}$ & $\%$ \\
\hline Umur & 27 & 65,8 \\
$\quad \begin{array}{l}\text { 20-35 tahun } \\
\quad 20 \text { dan > 35 tahun }\end{array}$ & 14 & 34,2 \\
\hline Jumlah anak & 36 & 87,8 \\
$\quad=2$ anak & 5 & 12,2 \\
$\quad>2$ anak & & \\
\hline Pendidikan & 23 & 56,1 \\
$\quad \begin{array}{l}\text { Rendah (tidak sekolah, SD,SMP) } \\
\quad \text { Tinggi (SMA, Perguruan Tinggi) }\end{array}$ & 18 & 43,9 \\
\hline $\begin{array}{l}\text { Pekerjaan ibu } \\
\text { Bekerja (karyawan, buruh, }\end{array}$ & 11 & 26,8 \\
$\begin{array}{l}\text { PNS, pedagang, petani penggarap } \\
\text { sawah, dll) }\end{array}$ & & \\
Tidak bekerja (ibu rumah & 30 & 73,2 \\
tangga) & & \\
\hline
\end{tabular}

Karakteristik responden lebih banyak yang berusia 20-35 tahun sebanyak $65,8 \%$, memiliki anak $\leq 2$ anak sebanyak $87,8 \%$, lebih banyak berpendidikan rendah sebanyak $56,1 \%$ dan lebih banyak tidak bekerja atau sebagai ibu rumah tangga sebanyak $73,2 \%$.

\section{Distribusi Frekuensi Sikap Ibu Menyusui terhadap Ketersediaan Pojok Laktasi}

Sikap ibu menyusui terhadap ketersediaan pojok laktasi lebih banyak yang tidak baik yaitu sebanyak $51,2 \%$. Kategori tidak baik bila responden memiliki nilai $<6,8$ atau sekurang-kurangnya tidak dapat menjawab pertanyaan tentang tujuan dan manfaat pojok laktasi (menyusui, menyimpan ASI, memerah ASI) sebanyak 5 pertanyaan dari total 10 pertanyaan tentang tujuan dan manfaat pojok laktasi. 
Tabel 2. Sikap ibu menyusui terhadap ketersediaan pojok laktasi

\begin{tabular}{lccc}
\hline $\begin{array}{c}\text { Sikap ibu menyusui } \\
\begin{array}{c}\text { terhadap } \\
\text { ketersediaan pojok } \\
\quad \text { laktasi }\end{array}\end{array}$ & kategori & n & $\%$ \\
\hline Baik & nilai $\geq 6,8$ & 21 & 51,2 \\
Tidak baik & nilai $<6,8$ & 20 & 48,8 \\
\hline Jumlah & & 41 & 100 \\
\hline
\end{tabular}

\section{Distribusi frekuensi perilaku ibu menyusui}

Perilaku ibu menyusui lebih banyak tidak baik sejumlah $58,5 \%$. Kategori tidak baik dalam variabel perilaku ibu menyusui adalah bila responden memiliki nilai $<6,2$ atau tidak dapat menjawab pertanyaan tentang cara menyusui, memerah ASI dan menyimpan ASI sebanyak 6 pertanyaan dari 15 pertanyaan tentang kebiasaan ibu menyusui, konsep menyusui, cara memerah ASI, cara menyimpan ASI.

Tabel 3. Perilaku ibu menyusui

\begin{tabular}{lccc}
\hline Perilaku ibu menyusui & Kategori & $\mathbf{n}$ & $\%$ \\
\hline Baik & Nilai $\geq 6,2$ & 17 & 41,5 \\
Tidak baik & Nilai $<6,2$ & 24 & 58,5 \\
\hline Jumlah & & 41 & 100 \\
\hline
\end{tabular}

\section{Distribusi Frekuensi Pemanfaatan Pojok Laktasi}

Pojok laktasi lebih banyak tidak dimanfaatkan yaitu sebanyak $60,9 \%$.

Tabel 4. Pemanfaatan pojok laktasi

\begin{tabular}{lcc}
\hline $\begin{array}{l}\text { Pemanfaatan } \\
\text { pojok laktasi }\end{array}$ & $\mathbf{n}$ & $\%$ \\
\hline $\begin{array}{l}\text { Memanfaatkan } \\
\text { Tidak }\end{array}$ & 16 & 39,1 \\
memanfaatkan & 25 & 60,9 \\
\hline Jumlah & 41 & 100 \\
\hline
\end{tabular}

5. Hubungan Sikap Ibu Menyusui Terhadap Ketersediaan Pojok Laktasi dengan Pemanfaatan Pojok Laktasi

Berdasarkan hasil kuesioner diperolah hubungan sikap ibu menyusui terhadap ketersediaan pojok laktasi adalah sebagai berikut.

Tabel 5. Hubungan sikap ibu menyusui terhadap ketersediaan pojok laktasi dengan pemanfaatan pojok laktasi

\begin{tabular}{|c|c|c|c|c|c|c|c|c|}
\hline \multirow{3}{*}{ Variabel } & \multicolumn{4}{|c|}{$\begin{array}{c}\text { Pemanfaatan pojok } \\
\text { laktasi }\end{array}$} & \multirow{3}{*}{$\chi^{2}$} & \multirow{3}{*}{$\mathbf{R P}$} & \multirow{3}{*}{$95 \% \mathrm{Cl}$} & \multirow{3}{*}{$p$} \\
\hline & \multicolumn{2}{|c|}{$\begin{array}{l}\text { Meman- } \\
\text { faatkan }\end{array}$} & \multicolumn{2}{|c|}{$\begin{array}{c}\text { Tidak } \\
\text { meman- } \\
\text { faatkan }\end{array}$} & & & & \\
\hline & $\mathrm{n}$ & $\%$ & $n$ & $\%$ & & & & \\
\hline \multicolumn{9}{|c|}{$\begin{array}{l}\text { Sikap ibu menyusui terhadap } \\
\text { ketersediaan pojok laktasi }\end{array}$} \\
\hline Baik & 10 & 47,6 & 11 & 52,4 & 1,34 & 1,58 & $0,70-3,55$ & 0,247 \\
\hline Tidak baik & 6 & 30,0 & 14 & 70,0 & & & & \\
\hline
\end{tabular}

Keterangan:

$p=p$ value $(*=$ Signifikan $p<0.05)$ 
Berdasarkan hasil analisis bivariabel pada Tabel 5 diperoleh bahwa $47,6 \%$ responden yang memiliki sikap yang baik terhadap ketersediaan pojok laktasi memanfaatkan pojok laktasi. Hasil analisis Tabel 5 menunjukkan bahwa secara praktis maupun statistik sikap ibu menyusui terhadap ketersediaan pojok laktasi yang baik tidak mempengaruhi pemanfaatan pojok laktasi dilihat dari nilai $p=0,247$ (RP1,58; 95\%
$\mathrm{Cl} 0,70-3,55)$. Artinya sikap ibu menyusui terhadap ketersediaan pojok laktasi yang bernilai baik positif 1,58 terhadappemanfaatan pojok laktasi.

\section{Hubungan Perilaku Ibu Menyusui dengan Pemanfaatan Pojok Laktasi}

Analisa hubungan perilaku ibu menyusui dengan pemanfaatan pojok laktasi dapat dilihat pada tabel sebagai berikut.

Tabel 6. Hubungan perilaku ibu menyusui dengan pemanfaatan pojok laktasi

\begin{tabular}{|c|c|c|c|c|c|c|c|c|}
\hline \multirow{3}{*}{ Variabel } & \multicolumn{4}{|c|}{ Pemanfaatan pojok laktasi } & \multirow{3}{*}{$\chi^{2}$} & \multirow{3}{*}{$\mathbf{R P}$} & \multirow{3}{*}{$95 \% \mathrm{Cl}$} & \multirow{3}{*}{$p$} \\
\hline & \multicolumn{2}{|c|}{$\begin{array}{l}\text { Meman- } \\
\text { faatkan }\end{array}$} & \multicolumn{2}{|c|}{$\begin{array}{c}\text { Tidak } \\
\text { memanfaat- } \\
\text { kan } \\
\end{array}$} & & & & \\
\hline & $\mathbf{n}$ & $\%$ & $\mathbf{n}$ & $\%$ & & & & \\
\hline \multicolumn{9}{|l|}{$\begin{array}{l}\text { Perilaku ibu } \\
\text { menyusui }\end{array}$} \\
\hline Baik & 10 & 58,8 & 7 & 41,2 & 4,78 & 2,35 & $1,05-5,23$ & 0,028 \\
\hline Tidak baik & 6 & 25,0 & 18 & 75,0 & & & & \\
\hline
\end{tabular}

Hasil analisis pada Tabel 6 memperlihatkan bahwa $58,8 \%$ responden yang memiliki perilaku menyusui yang baik akan memanfaatkan pojok laktasi. Hasil uji analisis chi square menunjukkan bahwa perilaku ibu menyusui yang baik berhubungan dengan pemanfaatan pojok laktasi baik secara praktis maupun statistik $(p=0,028, \mathrm{RP} 2,35$, 95\% Cl 1,05-5,23). Hal ini dapat diartikan bahwa perilaku ibu menyusui yang baik, akan 2,35 kali lebih tinggi dalam pemanfaatan dibandingkan perilaku yang tidak baik.

Berdasarkan hasil analisis bivariabel antara variabel bebas dengan variabel terikat bila diperoleh nilai $p<0,25$ maka dilanjutkan ke uji regresi logistik. Hasil analisis multivariabel dengan uji statistik regresi logistik diperoleh hasil pada Tabel 7.

Berdasarkan hasil analisis multivariable pada Tabel 7, model 2 lebih efektif dan efisien dalam memberikan kontribusi terhadap pemanfaatan pojok laktasi. Perilaku ibu menyusui yang baik sebesar 4,42 kali lebih tinggi dalam pemanfaatan pojok laktasi, sehingga perlu dipertimbangkan dalam intervensi secara menyeluruh dengan peningkatan sikap ibu menyusui yang baik. Kedua faktor tersebut memberikan kontribusi untuk pemanfaatan pojok laktasi sebesar $11 \%$, sisanya $89 \%$ dapat dipengaruhifaktor lain.

\section{Analisis Kualitatif}

\section{a. Responden yang Tidak Memanfaatkan}

Responden menyampaikan alasan tidak memanfaatkan karena kurangnya informasi tentang pojok laktasi juga.

"ga tau itu buat nyusuin. Ini puskesmas baru. dulu juga ga ada ruang gituan (menunjuk ke pojok laktasi). Nyusuin mah bisa dimana aja mba. di sini (diruang tunggu) juga bisa, wong bangku nya cuma satu masa mau antri...ntar 
Tabel 7. Analisis multivariabel

\begin{tabular}{|c|c|c|}
\hline \multirow[b]{2}{*}{ Variabel } & \multicolumn{2}{|c|}{ Pemanfaatan pojok laktasi } \\
\hline & $\begin{array}{c}\text { Model } 1 \\
\text { OR } \\
\text { Cl } 95 \% \\
\end{array}$ & $\begin{array}{c}\text { Model } 2 \\
\text { OR } \\
\text { Cl } 95 \% \\
\end{array}$ \\
\hline \multicolumn{3}{|l|}{ Perilaku ibu menyusui } \\
\hline Baik & $\begin{array}{c}4,28 \\
(1,12-16,31)\end{array}$ & $\begin{array}{c}4,42 \\
(1,12-17,35)\end{array}$ \\
\hline $\begin{array}{l}\text { Tidak baik } \\
\text { Sikap ibu menyusui terhada } \\
\text { pojok laktasi }\end{array}$ & 1 & 1 \\
\hline Baik & & $\begin{array}{c}2,24 \\
(0,56-8,84)\end{array}$ \\
\hline Tidak baik & & 1 \\
\hline $\mathbf{R}^{2}$ & 0,08 & 0.11 \\
\hline Deviance & 50.02 & 48.66 \\
\hline n & 41 & 41 \\
\hline
\end{tabular}

anakku nangis tambah keras. lagian cuma kursi sama kordein aja, terus juga sempit bangkunya cuma satu ya rebutan ntar kalo ada orang lain yang dateng bawa anaknya nangis juga harus gantian, ya ga mungkin. Disini (ruang tunggu) kan lebih nyaman ga pengap. Aku ga tau yang seharusnya gimana. Cuma kalo disuruh semua nyusuin disitu, mungkin ruangannya harus besar, jadi ga sempit kaya gitu ....R4"

"ini kan puskesmasnya baru pindah...di sana (letak puskesmas sebelumnya) dulu ga ada pojok laktasi, yang ada tulisan klinik laktasi. kami taunya itu ruang kantor petugas gizi, karena ada petugasnya didalemnya. Dulu di puskesmas lama, pernah ada yang suruh nyusuin disitu ya ga enak.. Jadi dulu netekin dimana aja, yang penting anak ga rewel. Kalo sekarang emang udah ada pojok laktasi, tapi cuma 1 kursi ya ngantri makenya. Masa suruh nunggu gantian, keburu anak nangis...terus juga belum ada yang suruh aku nyusuin disitu..... R.5"

Minimnya sosialisasi fungsi pojok laktasi membuat anggapan bahwa ketersediaan pojok laktasi bukan merupakan kebutuhan bagi masyarakat pengguna puskesmas. Hal tersebut juga didukung adanya anggapan di masyarakat bahwa kegiatan menyusui sejak dulu tidak dipengaruhi oleh ketersediaan pojok laktasi.

"dari dulu siy ga ada kaya gitu (pojok laktasi), anakku sudah 3 ini. Dulu...dulu ga ada kaya gini nyusui dimana aja bisa. Ga harus disitu. Orang dulu ga kenal pojok ASI yang bisa nyusuin mba. Aku juga belum pernah lihat ada orang kasih tau fungsi pojok laktasi, kalo pengin dikenal masyarakat di tv mungkin ya harus ada iklannya kaya iklan susu, kalo ga kaya itu (menunjuk poster yang ditempel di tembok) mungkin kalo disitu orang bisa baca mba, jadi orang bisa tau... R5"

"kalo menurutku, karena aku ga tau sebelumnya pojok laktasi itu apa. Mungkin dikasih papan pengumuman (pemberitahuan), ada tempat khusus buat menyusui bagi yang menyusui disitu (Puskesmas). Terus yang kedua dibagusin tempatnya, dicat, atau dikasih hiasan apa gitu mba, terus kursi buat nyusui jangan satu. Kalo lagi dipake orang ya yang lain ga bisa makai $R 4^{\prime \prime}$ 
Sedangkan yang memiliki sikap tidak baik, cenderung tidak memanfaatkan pojok laktasi. Hal tersebut sesuai dengan pernyataan responden sebagai berikut.

"Ada kaya gitu (pojok laktasi) marak e ribet. Bangku buat nyusui cuma satu, yang mau make banyak harus ngantri ya keburu anak rewel... Nyusui tinggal nyusui, dari dulu ga ada kaya gituan...R5."

"Aku baru tahu ada kaya gitu, karena di puskesmas dulu ga ada kaya gitu. Ini kan puskesmas baru, dulu ga ada kaya gini di puskesmas lama. Mungkin karena fasilitas puskesmas baru, ntar kalo sudah lama ya mungkin ga ada lagi mba....tau sendiri kalo baru banyak yang make kalo sudah lama ya banyak yang ga make lagi... R4"

Ibu yang berperilaku tidak baik cenderung tidak memanfaatkan pojok laktasi yang sesuai dengan wawancara sebagai berikut.

"anakku tak kasih susu botol juga, karena dari lahir juga langsung dikasih susu botol. Wong dokternya sendiri yang nganjurin kasih susu botol, karena aku sesar masih sakit. ASI nya siy keluar, tapi kalo ditinggal ya aku kasih susu botol......R6"

"aku kasih susu botol, karena aku kerja, ga mungkin anak aku dibawa kerja kalo ga dikasih susu botol. Ya to ? suamiku ga masalah anakku kasih susu botol, waktu baru lahir juga sama bidan ga masalah kalo anakku aku kasih susu botol...R4"

Dukungan dari suami, mertua dan lingkungan sangat mempengaruhi perilaku ibu untuk menyusui. Hal tersebut sesuai dengan pernyataan responden sebagai berikut.

"anakku 3 bulan, aku kasih ASI eksklusif ko. Soalnya dia dikasih susu botol ga mau. Sama suami dibeliin susu katanya anaknya temen suami dikasih susu itu jadi pinter tapi anakku ga mau, mau gimana lagi. Kata suami dikasih susu botol karena aku kerja ntar kalo aku berangkat kerja lagi anakku rewel.....R4."

Seorang ibu yang mempunyai anak 4 bulan menyatakan bahwa pemberian tambahan makanan selain ASI diberikan sebelum usia 6 bulan karena anjuran dari mertua, hal tersebut sesuai pernyataannya sebagai berikut.

"ya masih eksklusif wong ga dikasih susu botol. Sama mertua disuruh kasih pisang tapi seringnya ga mau, bubur tim tapi cuma kadang-kadang kalo lagi rewel, katanya kalo rewel terus kurang kenyang. Waktu baru lahir dikasih madu karena ASIku bening katanya mertua bikin bayi muntah jadi ga kukasihkan. Saya ikut aja sama orangtua, karena merekakan udah pengalaman dari dulu besarin suami saya, buktinya suami saya sehat sampai sekarang....R6".

\section{b. Responden yang Memanfaatkan}

Alasan responden yang memanfaatkan dan memiliki sikap baik terhadap ketersedian pojok laktasi menyatakan bahwa ibu menyusui perlu privasi sehingga harus ada pojok laktasi di tempat umum. Responden berbeda dengan masyarakat atau ibu menyusui pada umumnya disana karena kebanyakan mereka tidak segan membuka payudara untuk menyusui. Walaupun responden tersebut adalah ibu rumah tangga berpendidikan rendah dan belum pernah mengetahui fungsi pojok laktasi akan tetapi tetap menggunakan pojok laktasi menjaga privasi. Seperti yang disampaikan dalam wawancara sebagai berikut.

"Sebenarnya malu, kalo terpaksa pojok laktasinya lagi dipake anak sudah nangis, mau ga mau nyusuin di ruang tunggu, soalnya bangku pojok laktasi dan kordeinnya kan cuma 1. Lebih nyaman ga terlihat orangorang, walaupun menyusui adalah hal biasa, tapi kali payudara terlihat kan malu. aku belum pernah tau sebelumnya, tau pojok laktasi dari tulisan,sama dari orang-orang 
yang kadang nyusuin disitu. Kalo bu dokter atau bu bidan atau pegawai puskes belum ada yang kasih tau. Lihat poster atau spanduk pojok laktasi juga belum pernah mba....R6" "ya walaupun cuma hanya sekedar kursi buat nyusuin gini saya sudah bersyukur, puskesmas lain ga ada kaya ginian (pojok laktasi) diruang tunggu adanya tulisan pojok ASI tapi buat ruang kerja orang puskes. Mending nyusuin disini jadi lebih tenang walaupun mungkin ga sesuai yang seharusnya....R2"

Responden menyatakan bahwa mereka masih memberikan ASI kepada bayinya karena bayinya tidak mau diberi susu formula, dan mereka sebagian besar menggunakan pojok laktasi untuk menyusui saja. Fungsi pojok laktasi yang lain sebagai tempat memeras ASI dan menyimpan ASI tidak dimanfaatkan karena ketiadaan fasilitas pendukung dan pengunjung hanya berkunjung ke puskesmas yang tidak memerlukan waktu lama untuk terpisah dengan bayinya dan sebagian besar membawa bayinya ke puskesmas. Hal tersebut dapat dilihat dalam hasil wawancara sebagai berikut.

"aku masih kasih ASI untuk anakku karena dia ga mau dikasih susu formula, mau gimana lagi. Jadi rewang yang nyusulin anakku ke sini (puskesmas). Aku makai pojok laktasi buat nyusuin aja, ga pernah meres ASI, ribet lah, ga sempet juga. ntar waktunya habis kerjaan ga kepegang....R3" Ibu menyusui yang bekerja di Puskesmas.

"aku ASI eksklusif ko, wong sekarang masih menyusui. Anakku masih 4 bulan sekarang. Gimana ga ASl eksklusif anakku dikasih susu botol ga mau, dikasih madu atau yang lain juga ga mau. Ya jadinya sampai sekarang masih ASI eksklusif. Aku makai pojok laktasi cuma buat nyusuin aja, emang bisa buat apa lagi ? tulisannya pojok laktasi ya buat nyusuin aja to......R 5" Ibu rumah tangga yang menyusui yang memiliki anak 4 bulan. "sebenernya anakku udah dikasih susu formula, tapi masih aku kasih ASI wong baru 3 bulan. Kalo aku kerja dikasih susu formula, kalo aku dirumah ya tak kasih ASI. aku makai ruangan ini baru pertama kali, karena liat tadi ada yang makai buat nyusuin. Sebelumnya ga tau, petugas puskes juga belum pernah kasih tau tentang pojok laktasi. Tau nya ini pojok laktasi karena ada tulisannya pojok laktasi.... $R 6^{\prime \prime}$ ibu bekerja yang menyusui

Pada responden yang memanfaatkan diperoleh informasi bahwa mereka memanfaatkan karena sering melihat ruangan tersebut untuk menyusui, tapi tidak pernah ada sosialisasi tentang fungsi pojok laktasi yang seharusnya. Sesuai dengan hasil wawancara sebagai berikut.

"aku makai buat menyusui, tapi ga pernah aku makai buat meras atau nyimpen ASI...ga tau caranya juga cara meras atau nyimpan.... lagian aku cuma dateng buat priksa anakku 1 jam paling lama habis itu pulang? Adanya cuma dipuskesmas aja kan mba, aku ga tau kalo ditempat umum harus ada, selama ini juga aku ga pernah nemuin ditempat umum... $R 6^{\prime \prime}$ pengunjung ibu menyusui yang bekerja

"aku makai buat nyusuin aja kalo pas lagi ke puskes. Setauku adanya hanya di puskes di tempat lain ga ada. Ga pernah tau buat apa, wong tulisannya cuma pojok laktasi buat nyusuin aja berarti kan? belum pernah liat poster atau spanduk tentang pojok laktasi, petugas juga ga pernah kasih tau tentanng ruang itu....R4".

Sebagian responden yang bersikap baik memiliki kecenderungan memanfaatkan pojok laktasi, walaupun tidak disertai dengan pengertian yang benar tentang fungsi dan tujuan pojok laktasi. Peran kepala puskesmas sangat berpengaruh. Hal tersebut sesuai dengan hasil wawancara dengan responden yaitu sebagai berikut. 
“Aku make pojok laktasi untuk menyusui. Aku ga pernah make untuk menyimpan ASI. Wong ga ada kulkasnya. Nyatanya ya jarang yang mau meres ASI. Bagus siy ada pojok laktasi jadiga malu nyusui buka-buka payudara, kalo ga ada ruangannya kan isin (malu). Kalo ada itu kan dikhususkan buat nyusuin... R3" ibu bekerja di Puskesmas

"disini kepala puskesmasnya sangat mendukung dengan program ASl eksklusifsehingga pojok laktasi benar-benar ditekankan pemanfaatan disini mba, sebelum saya melahirkan juga sudah disuruh untuk ASI eksklusif dengan menyediakan pojok laktasi agar kami bisa bekerja tapi tetapi ASI eksklusif" R2 ibu bekerja di Puskesmas

Untuk meningkatkan pemanfaatan pojok laktasi responden menyampaikan perlu adanya perhatian kepala puskesmas untuk membuat anggaran. Selain itu jika kepala puskemas yang menganjurkan bawahan akan lebih giat untuk memanfaatkan dan memeliharanya. Seperti yang disampaikan responden berikut.

"saya makai pojok laktasi untuk menyusui, karena anak saya dicoba dikasih susu botol ga mau. Ya terpaksa rewang nyusulin ke sini dari pada rewel. Lagian bu dokter (Kepala Puskesmas) nyuruh semua yang kerja di puskesmas ini yang menyusui buat makai pojok laktasi. Kebetulan di Pukesmas ini kan sudah dibikin dua, satu dibawah untuk pengunjung Puskesmas, yang diatas untuk pegawai. Disini sama dibawah juga sudah pada sering dipakai buat menyusui. Kalo ada anggaran khusus alokasi pojok laktasi mungkin akan bisa terealisasi pojok laktasi sesuai yang seharusnya... R2."ibu menyusui yang bekerja di Puskesmas I Cilongok "rencananya Saya mau nyediain semacam baby sitter untuk ngasuh anak para pegawai yang menyusui yang bekerja disini, jadi kalo para pegawai puskes lagi kerja anaknya bisa dibawa ke Puskesmas, kerjanyabisa tenang karena ga kepikiran anak dirumah. Waktunya menyusui ya bisa menyusui to mba. selain itu ga ada lagi alasan tidak ada lagi alasan tidak ASI eksklusif karena bekerja to....R1"Kepala Puskesmas I Cilongok yang merupakan ibu menyusui

"menurut saya minimnya informasi kepada masyarakat tentang pojok laktasi membuat orang tidak memanfaatkan pojok laktasi. Untuk menarik supaya orang memanfaatkan, lokasi penempatan harus mudah dijangkau. Harus ada pemberitahuan bahwa ditempat itu ada pojok laktasi, selain itu tempatnya harus bersih, dicat dengan warna yang menarik, ada ornamen menarik dan mungkin harus ada pendingin ruangan. Sehingga diperlukan anggaran khusus untuk pengadaan pojok laktasi yang sesuai dengan peraturan. Sayangnya, pengadaan alokasi dimasingmasing puskesmas beda-beda, tergantung kepala puskesmasnya concern atau ga terhadap ASI eksklusif, walaupun secara peraturan sudah ada untuk mengadakan pojok laktasi di masing-masing puskesmas... R1."

Pemanfaatan pojok laktasi sesuai dengan fungsi dan tujuan pojok laktasi membutuhkan sosialisasi menggunakan penyuluhan dan media sehingga dapatdiaplikasikan secara benar dan sesuai fungsi pojok laktasi.

“disini pojok laktasinya cuma hanya ada kursi sama kordain (tirai), itu juga udah mending dari puskesmas lain, yang hanya sebatas tulisan pojok laktasi tapi setelah dibuka ruangan itu isinya bangku kosong, ruangan kosong atau malah kantor klinik gizi di puskesmas....R2" 


\section{Sikap Ibu Menyusui tentang Ketersediaan Pojok Laktasi}

Sikap ibu menyusui merupakan kemampuan menjawab responden terkait dengan tujuan adanya pojok laktasi dan pemahaman tentang manfaat ketersediaan pojok laktasi. Sikap yang baik bila responden mampu menjawab lebih dari 5 pertanyaan kuesioner yang mengukurkemampuan seorang ibu menyusui mengerti tentang tujuan dan manfaat pojok laktasi memberikan efek terhadap pemanfaatan pojok laktasi.Hal tersebut sesuai dengan penyataan Anderson bahwa pemanfaatan pelayanan kesehatan dipengaruhi oleh faktor keyakinan terhadap kesehatan yang meliputi sikap atau pandangan seseorang terhadap sehat sakit, keyakinan bahwa pelayanan kesehatan dapat menolong proses penyembuhan penyakit. ${ }^{5}$ Pernyataan tersebut sesuai dengan penelitian ini yang menyatakan bahwa responden yang bersikap baik cenderung memanfaatkan pojok laktasi sebagai fasilitas pelayanan kesehatan.

Hasil penelitian menunjukkan sebanyak 21 orang atau $51,2 \%$ responden memiliki sikap baik. Hal tersebut sudah menggambarkan bahwa masih cukup banyak masyarakat yang kurang mengerti tentang untuk apa pojok laktasi diadakan.

Hal tersebut didukung dengan hasil wawancara dengan ibu menyusui bahwa masyarakat yang sudah memiliki pola menyusui yang salah akan memperburuk rendahnya pemanfaatan pojok laktasi. Sikap masyarakat yang cenderung kurang memanfaatkan ketersediaan pojok laktasi karena mereka cenderung menggunakan susu formula sebagai pendamping ASI disaat anak mereka berusia kurang dari 6 bulan. Apalagi jika ibu seorang wanita bekerja, akan dapat menjadi alasan untuk memberikan susu formula disaat bayi ditinggal bekerja. Keadaan itu diperparah dengan bayi yang sudah diberikan susu formula sejak baru lahir. Budaya masyarakat setempat masih memberikan cairan prelakteal seperti madu atau air tajin karena mereka menganggap kolostrum yang merupakan cairan encer yang tidak membuat bayi kenyang sehingga bayi selalu rewel. Hal tersebut semakin mendukung rendahnya ASI eksklusif dikarenakankuatnya peran suami, orang tua serta mertua dalam membuat keputusan untuk melaksanakan ASI eksklusif atau tidak memberikan tambahan makanan apapun sebelum usia 6 bulan.

Profesi ibu sebagai ibu rumah tangga atau ibu bekerja menjadi salah satu faktor yang mempengaruhi sikap ibu menyusui terhadap ketersediaan pojok laktasi. Berdasarkan hasil wawancara ibu bekerja yang menyusui dikarenakan faktor kurangnya dukungan waktu, dukungan rekan kerja serta dukungan atasan. Atasan yang mendukung upaya ASI eksklusif akan menekankan program atau kebijakan menyusui kepada bawahannya serta menyediakan fasilitas pendukung untuk program tersebut. Namun kesadaran sikap ibu menyusui untuk melaksanakan ASI eksklusif harus sejalan, dengan praktek memberikan susu formula. Responden menganggap bahwa ASI eksklusif untuk diterapkan saat bekerja adalah tidak sesuai dikarenakanmerepotkan. Akhirnya susu formula adalah solusi dari ibu bekerja yang menyusui dan yang tidak mau repot, bukan pojok laktasi.

Hal tersebut sesuai dengan penelitian Hirani dan Karmaliani yang menyatakan bahwa sikap ibu menyusui yang bekerja akan mempengaruhi keputusan seorang ibu untuk terus menyusui dengan cara memanfaatkan fasilitas (pojok laktasi) yang berada di kantornya. ${ }^{6}$ Selain itu keputusan ibu untuk menyusui dipengaruhi oleh lingkungan tempat kerja seperti atasan, rekan kerja, ketersediaan pojok laktasi, fleksibilitas jenis pekerjaan.

Hirani dan Karmaliani juga menekankan menyatakan bahwa ibu bekerja untuk dapat melanjutkan menyusui di tempat kerja diperlukan pendidikan tentang bagaimana wanita bekerja tetap menyusui, pengaturan fasilitas pojok laktasi, menyediakan tempat penitipan anak, breast pump, dan tempat penyimpanan $\mathrm{ASI}^{7}$ 
Azhari et al menyampaikan bahwa sikap positif seorang ibu menyusui di Malaysia semakin baik sehingga kebutuhan pojok laktasi (Baby Care room) di Malaysia menunjukkan peningkatan. Hal tersebut dapat dilihat bahwa pusat perbelanjaan di Malaysia mengalami peningkatan jumlah pojok laktasi. ${ }^{8}$

Menurut Jolly ${ }^{9}$ faktor keberhasilan program menyusui saat bekerja yang salah satunya berupa ketersediaan pojok laktasi adalah sikap ibu menyusui untuk memanfaatkan fasilitas pendukung menyusui, sikap rekan kerja, kebijakan yang baik dan pendidikan karyawan.

Namun, Hal tersebut tidak sesuai dengan hasil analisis Tabel 5 yang menunjukkan bahwa secara praktis sikap ibu menyusui terhadap ketersediaan pojok laktasi yang baik tidak mempengaruhi pemanfaatan pojok laktasi salah satu keterbatasan dalam penelitian ini adalah sampel yang kecil dan cara pengambilan sampel menjadikan hasil dari analisis data ini tidak dapat digeneralisir. Untuk itu metode kualitatif dengan mengungkap pandangan responden melalui wawancara in depth interview dengan panduan kuesioner menjadi alternatif untuk melengkapi kekurangan dari analisa kuantitatif ini. Penggunaan penelitian kualitatif digunakan untuk mengklarifikasi jawaban responden yang bersifat normatif dalam menjawab kuesioner, sehingga diharapkan dengan metode wawancara mendapatkan jawaban sesuai dengan hasil observasi yang dilakukan oleh peneliti.

\section{Perilaku Ibu Menyusui}

Perilaku ibu menyusui merupakan gambaran persepsi ibu dalam menanggapi pertanyaan tentang bagaimana kebiasaan menyusui, cara memerah ASI dan menyimpan ASI. Kategori baik dalam hal ini jika responden dapat menjawab sekurang-kurangnya 9 dari 15 pertanyaan. Dari 9 pertanyaan tersebut dapat menggambarkan bahwa responden mengerti konsep menyusui, cara menyusui, memerah dan menyimpan ASI dengan benar. Gambaran ini dapat mewakili penilaian perilaku ibu menyusui yang baik dengan mampu menjawab pertanyaan kuesioner. Hasil analisis univariabel menunjukkan bahwa sebanyak 24 responden atau $58,5 \%$ memiliki perilaku tidak baik dan mereka cenderung tidak memanfaatkan pojok laktasi. Seorang ibu yang memiliki konsep dan pemahaman yang baik tentang ASI dan bagaimana cara mengelola ASI akan cenderung melaksanakan ASI eksklusif dengan menggunakan pojok laktasi ketika tidak atau bersama bayinya.

Pojok laktasi merupakan tempat untuk melakukan kegiatan menyusui, memerah, dan menyimpan ASI. Yang menjadi tujuan utama adanya pojok laktasi adalah melaksanakan ASI eksklusif dan memberikan hak bayi yaitu mendapatkan ASI segera setelah lahir sampai sebelum 6 bulan dengan eksklusif. Gambaran perilaku ibu menyusui di Puskesmas I Cilongok menjadi salah satu tolak ukur pemanfaatan pojok laktasi. Rendahnya pemahaman tentang menyusui, menyimpan dan memerah ASI menjadi faktor rendahnya pemanfaatan pojok laktasi.

Menurut Green ${ }^{10}$ salah satu faktor terbentuknya perilaku disebabkan karena tersedia atau tidaknya fasilitas dan sarana kesehatan dalam hal ini pojok laktasi. Sedangkan menurut Rimer and Glanz perilaku dapat dipengaruhi oleh kepercayaan, persepsi, demografi, pengetahuan, ancaman dan terdapatnya faktor pencetus isyarat untuk bertindak dalam hal ini pojok laktasi.

Hal tersebut sesuai dengan hasil wawancara dengan responden yang menyatakan mereka tidak pernah melakukan kegiatan memerah dan menyimpan ASI di pojok laktasi. Responden hanya melaksanakan kegiatan menyusui saja di ruangan tersebut. Selain dikarenakan ketidaktahuan tentang fungsi pojok laktasi hal tersebut juga karena kurangnya fasilitas yang mendukung. Pojok laktasi yang ada hanya berupa bangku dan korden saja. Fasilitas pendukung seperti kulkas, tempat cuci tangan dan luas ruangan tidak sesuai dengan standar minimal, sehingga semakin mendukung rendahnya pemanfaatan pojok laktasi di puskesmas tersebut. Minimnya jumlah tempat menyusui yang hanya disediakan 1 bangku dikarenakan keterbatasan 
alokasi anggaran serta anggapan bahwa ibu menyusui tidak terpengaruh kegiatan menyusuinya menjadi hal yang menyebabkan rendahnya pemanfaatan pojok laktasi.

Budaya masyarakat pedesaan yang menganggap bahwa membuka payudara di depan umum merupakan hal biasa juga menjadi faktor pendukung rendahnya pemanfaatan pojok laktasi. Menyusui di depan umum bagi masyarakat pedesaan menjadi hal yang biasa karena sudah menjadi kodrat seorang wanita untuk menyusui. Hal tersebut menjadikan masyarakat kurang menganggap pojok laktasi perlu untuk berada di puskesmas ataupun fasilitas umum.

Dalam penelitian Li et al menyatakan bahwa pemanfaatan pojok laktasi di tempat umum salah satunya disebabkan karena anggapan di Amerika Serikat bahwa menyusui ditempat umum dianggap tabu dan tidak diterima dimasyarakat modern. Hal tersebut yang membuat sikap ibu menyusui mendukung adanya pojok laktasi didirikan ditempat umum, mal dan gedung publik. ${ }^{11}$ Namun berbeda dengan di Indonesia, kebiasaan masyarakat yang tidak menganggap tabu ketika membuka payudara untuk menyusui menjadi salah satu penyebab pojok laktasi tidak dimanfaatkan oleh masyarakat. Masyarakat di sekitar tempat penelitian yang termasuk dalam kategori pedesaan menganggap hal yang wajar seorang ibu menyusui dimana saja dengan memperlihatkan payudaranya didepan umum karena memang sudah kodrat mereka menyusui.

Ibu bekerja cenderung tidak memanfaatkan pojok laktasi yang ada dikarenakan kurangnya dukungan rekan kerja serta keterbatasan fasilitas. Anggapan bahwa menyimpan dan memerah ASI tidak perlu dilakukan dikarenakan karena banyaknya susu formula yang menawarkan banyak keunggulan dari pada ASI sehingga susu formula seolah-olah menjadi semacam solusi ketika ibu harus bekerja dan tidak berada satu tempat dengan anaknya.

Hal tersebut sesuai dengan penelitian Jacknowitz yang menyatakan bahwa perilaku ibu menyusui pada ibu bekerja mempengaruhi pemanfaatan pojok laktasi di tempat kerja mereka. ${ }^{11}$ Ibu yang berusaha menyusui lebih besar memanfaatkan fasilitas pendukung menyusui dari pada ibu yang tidak menyusui secara eksklusif.

Menurut O'Gara et al durasi ibu bekerja untuk menyusui dipengaruhi juga karena perilaku ibu menyusui yang bekerja dalam memanfaatkan fasilitas menyusui seperti memerah ASI, tempat penyimpanan ASI, ruang laktasi. Namun hal tersebut dapat dilakukan jika rekan kerja, lingkungan dapat mendukung serta dukungan budaya, kebijakan tempat kerja, dukungan tempat kerja, kelompok juga individu. ${ }^{13}$

Berdasarkan hasil uji analisis chi square menunjukkan bahwa perilaku ibu menyusui yang baik berhubungan dengan pemanfaatan pojok laktasi baik secara praktis maupun statistik. Hasil analisis mendukung hasil wawancara yang dilakukan dengan responden, namun untuk menjadikan sebagai acuan bahwa analisa bivariabel perilaku dan pemanfaatan terdapat hubungan agak sulit dijadikan acuan dikarenakan jumlah sampel yang sedikit, serta cara pengambilan sampel yang menjadi salah satu keterbatasan dalam penelitian ini. Analisis multivariabel dilakukan untuk mengurangi unbias estimated dalam penelitian ini. Berdasarkan hasil analisis multivariabel yang dilakukan diperoleh model 2 yang merupakan kombinasi dari sikap ibu menyusui dan perilaku ibu menyusui berpengaruh terhadap pemanfaatan pojok laktasi sehingga berdasarkan analisis ini model 2 yang dianjurkan karena nilai OR 2 lebih besar dari nilai OR 1. Hasil tersebut dapat menyempurnakan kelemahan dari penelitian kuali-tatif yang dilakukan.

Integrasi antara tenaga kesehatan dan masyarakat untuk sosialisasi dan pemanfaatan pojok laktasi akan menjadikan pojok laktasi yang ada dan yang akan diadakan dapat dimanfaatkan dengan optimal. Penggunaan media cetak seperti poster dan sejenisnya yang diposisikan ditempat yang mudah diakses atau dibaca oleh masyarakat menjadi salah satu alternatif untuk mensosialisasikan program ini. Kepala puskesmas atau pihak dinas terkait perlu mengupayakan pojok laktasi menjadi menarik 
sehingga meningkatkan ibu menyusui untuk dapat memanfaatkan dengan optimal. Namun harus diterapkan sesuai dengan standar minimal sesuai peraturan yang berlaku. Desain yang disesuaikan dengan konsep ibu menyusui dan bayi sehingga dapat menarik perhatian masyarakat untuk mengoptimalkan. Sosialisasi dari pihak terkait yaitu pihak dinas kesehatan dan pemerintah daerah tentang penekanan ketersediaan pojok laktasi di fasilitas umum, perkantoran dan pusat pelayanan publik akan dapat dimaksimalkan jika sudah muncul kesadaran untuk memanfaatkan pojok laktasi sehingga tujuan utama melaksanakan ASI eksklusif untuk bayi usia 0-6 bulan dapat dilaksanakan.

Konsep ASI eksklusif yang dimiliki oleh ibu menyusui nampaknya perlu diperbaiki. Perlu adanya penekanan yang jelas bahwa ASI eksklusif merupakan kesadaran seorang ibu untuk tidak menguji cobakan bayinya dengan zat yang lain selain ASI. Pada praktek dilapangan ASI eksklusif dilakukan jika bayi tidak mau mengkonsumsi susu formula atau tidak mau menggunakan botol. Oleh karena itu dibutuhkan edukasi kepada ibu hamil sebelum mereka menyusui tentang keunggulan dan kelebihan ASI daripada susu formula, sehingga kesadaran akan melaksanakan ASI eksklusif yang berujung dengan meningkatnya kebutuhan dan pemanfaatan pojok laktasi akan muncul dengan sendirinya. Perlu dipikirkan metode indoktrinasi tentang keunggulan ASI daripada susu formula sehingga ibu berpikir 1000 kali untuk memberikan susu formula pada bayinya.

Tidak tersedianya fasilitas penunjang, sesuai dengan syarat berdirinya pojok laktasi lebih banyak dikarenakan kurangnya anggaran khusus pengadaan barang-barang tersebut. Perhatian dari kepala puskesmas selaku pemegang kendali dari pengadaan pojok laktasi di puskesmas menjadi salah satu faktornya. Hal tersebut dapat dilihat dari pengadaan setiap tahunnya, bahwa atasan memberikan dukungan terhadap program pengadaan pojok laktasi atau tidak. Kurangnya dukungan dari kepala puskesmas terhadap program ini memberikan dampak yang berbeda terhadap kebijakan yang ada di puskesmas. Karyawan lebih cenderung mengikuti anjuran atasan jika disarankan dalam mamanfaatkan pojok laktasi. Namun demikian kesadaran dari karyawan untuk memanfaatkan pojok laktasi itu lebih besar dampaknya dalam penggunaan pojok laktasi. Dukungan atasan yang tidak disertai dengan kesadaran hanya akan memberikan dampak sementara dalam pemanfaatan pojok laktasi ini. Apabila kepala puskesmas telah berganti, maka jika tidak disertai kesadaran maka pojok laktasi ini akan tidak berfungsi.

Dari wawancara dengan responden menyatakan bahwa mereka cenderung kurang membutuhkan pojok laktasi. Anggapan tersebut semakin diperkuat dengan penilaian masyarakat bahwa tanpa pengadaan pojok laktasi di puskesmas, mereka telah dapat memberikan ASI dimanapun mereka berada sehingga mereka tidak membutuhkan kebijakan ini. Sikap dan perilaku masyarakat yang tidak baik semata-mata tidak merupakan faktor utama dari rendahnya pemanfaatan pojok laktasi ini tetapi karena mereka tidak membutuhkannya. Untuk itu perlu dipikirkan bahwa pengadaan kebijakan hendaknya tidak hanya disesuaikan dengan masalah saja tapi juga dilihat dari faktor kebutuhan sesuai keadaan sebenarnya.

\section{KESIMPULAN DAN SARAN}

Sikap ibu menyusui terhadap ketersediaan pojok laktasi yang baik tidak mempengaruhi pemanfaatan pojok laktasi di Puskesmas I Cilongok Kabupaten Banyumas. Perilaku ibu menyusui yang baik dapat mempengaruhi pemanfaatan pojok laktasi di Puskesmas I Cilongok Kabupaten Banyumas. Ibu menyusui di Puskesmas I Cilongok lebih banyak yang tidak memanfaatkan pojok laktasi daripada yang memanfaatkan. Pemanfaatan pojok laktasi di Puskesmas I Cilongok hanya untuk menyusui saja, sedangkan memerah, menyimpan ASI tidak dilakukan. Rendahnya pemanfaatan pojok laktasi juga dikarenakan masyarakat kurang membutuhkan pojok laktasi ini sehingga mereka cenderung tidak memanfaatakan. 


\section{DAFTAR PUSTAKA}

1. American Academy of Pediatrics. Breastfeeding and the use of human milk. Pediatrics. 2012;129(3): e827-e41.

2. Badan Pusat Statistik, Macro International. Survei Demografi dan Kesehatan Indonesia (SDKI) tahun 2007. Calverton, Maryland, USA: Macro International; 2008.

3. Badan Pusat Statistik Provinsi Jawa Tengah. Profil Kesehatan Jawa Tengah 2012. Semarang: Badan Pusat Statistik Provinsi Jawa Tengah; 2012.

4. Bupati Banyumas. Peraturan Bupati Banyumas nomor 52 tahun 2012 tentang Peningkatan Pemberian Air Susu Ibu di Kabupaten Banyumas,. In: Banyumas B, editor. Banyumas: Bupati Banyumas; 2012.

5. Anderson R. Revisiting The Behavioral Model and Access to Medical Care : does it Mater? Los Angeles: University of California; 1995.

6. Hirani SAA, Karmaliani R. The experiences of urban, professional women when combining breastfeeding with paid employment in Karachi, Pakistan: A qualitative study. Women and birth. 2013;26 (2013):147-51.
7. Hirani SAA, Karmaliani R. Evidence based workplace interventions to promote breastfeeding practices among Pakistani working mothers. Women and birth. 2011;26 (2013):10-6.

8. Azhari NFN, Salam H, Hasbullah MN. Baby care Room in Shopping Malls: Accessibility to malaysian Public. Procedia (Social and Behavioral sciences). 2011;35 (2012):531-8.

9. Jolly R. Breastfeeding and health care service. International federation of Gynocology and Obstetrics. 1990;31:7-9.

10. Green L. Health Education planning A diagnostic approach. Baltimore: The John Hopkin University mayfield Publising Co; 1980.

11. Li R, Hsia J, Fridinger f, Hussain A, Davis SB, Strawn LG. Public beliefs about breastfeeding policies in various settings. J Am Diet Assoc. 2004;104:11628.

12. Jacknowitz A. Understanding Gains in Breastfeeding Rates, promising policies and programs. Women's health Issues. 2006;16(2006):101-3.

13. O'Gara C, Canahuati J, Martin AM. Every mother is a working mother: breastfeeding and women's work. International federation of Gynocology and Obstetrics. 1994;47 (1994):533-9. 